Provided for non-commercial research and education use. Not for reproduction, distribution or commercial use.

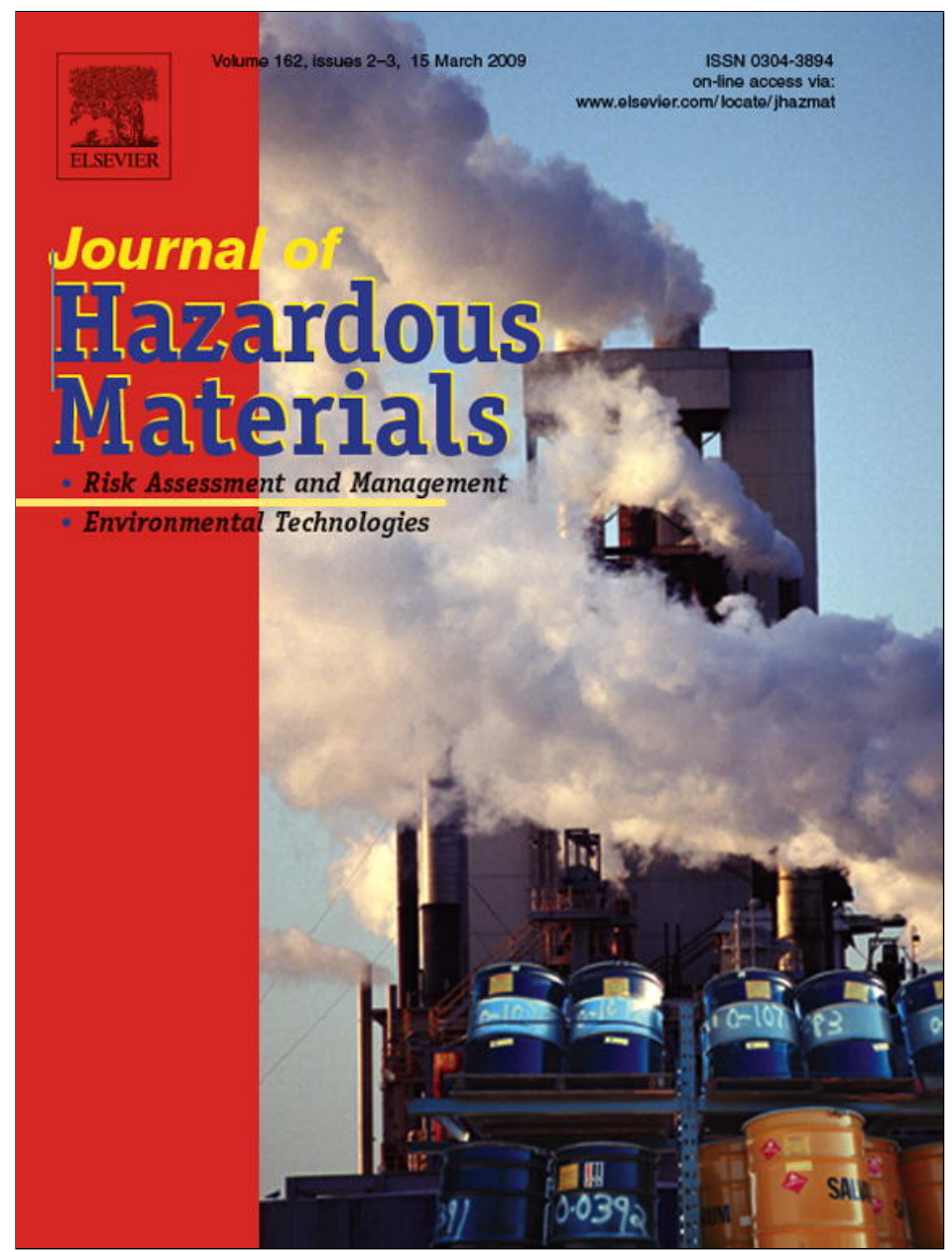

This article appeared in a journal published by Elsevier. The attached copy is furnished to the author for internal non-commercial research and education use, including for instruction at the authors institution and sharing with colleagues.

Other uses, including reproduction and distribution, or selling or licensing copies, or posting to personal, institutional or third party websites are prohibited.

In most cases authors are permitted to post their version of the article (e.g. in Word or Tex form) to their personal website or institutional repository. Authors requiring further information regarding Elsevier's archiving and manuscript policies are encouraged to visit:

http://www.elsevier.com/copyright 


\title{
In search of a reliable technique for the determination of the biological stability of the organic matter in the mechanical-biological treated waste
}

\author{
Raquel Barrena ${ }^{\mathrm{a}}$, Giuliana d'Imporzano ${ }^{\mathrm{b}}$, Sergio Ponsáa ${ }^{\mathrm{a}}$, Teresa Gea ${ }^{\mathrm{a}}$, Adriana Artola ${ }^{\mathrm{a}}$, \\ Felícitas Vázquez ${ }^{\mathrm{c}}$, Antoni Sánchez ${ }^{\mathrm{a}, *}$, Fabrizio Adani ${ }^{\mathrm{b}}$ \\ ${ }^{a}$ Composting Research Group, Chemical Engineering Department, Universitat Autònoma de Barcelona, Bellaterra, Cerdanyola, 08193 Barcelona, Spain \\ b Dipartimento di Produzione Vegetale, Università Degli Studi di Milano, Via Celoria 2, I-20133 Milano, Italy \\ c Institute of Biotechnology and Biomedicine, Universitat Autònoma de Barcelona, Bellaterra, Cerdanyola, 08193 Barcelona, Spain
}

\section{A R T I C L E I N F O}

\section{Article history:}

Received 10 January 2007

Received in revised form 28 April 2008

Accepted 29 May 2008

Available online 3 June 2008

\section{Keywords:}

Biogas

Composting

Mechanical-biological treatment

Municipal solid wastes

Respirometry

\begin{abstract}
A B S T R A C T
The biological stability determines the extent to which readily biodegradable organic matter has decomposed. In this work, a massive estimation of indices suitable for the measurement of biological stability of the organic matter content in solid waste samples has been carried out. Samples from different stages in a mechanical-biological treatment (MBT) plant treating municipal solid wastes (MSW) were selected as examples of different stages of organic matter stability in waste biological treatment. Aerobic indices based on respiration techniques properly reflected the process of organic matter biodegradation. Static and dynamic respirometry showed similar values in terms of aerobic biological activity (expressed as oxygen uptake rate, OUR), whereas cumulative oxygen consumption was a reliable method to express the biological stability of organic matter in solid samples. Methods based on OUR and cumulative oxygen consumption were positively correlated. Anaerobic methods based on biogas production (BP) tests also reflected well the degree of biological stability, although significant differences were found in solid and liquid BP assays. A significant correlation was found between cumulative oxygen consumption and ultimate biogas production. The results obtained in this study can be a basis for the quantitative measurement of the efficiency in the stabilization of organic matter in waste treatment plants, including MBT plants, anaerobic digestion of MSW and composting plants.
\end{abstract}

(c) 2008 Elsevier B.V. All rights reserved.

\section{Introduction}

The growing environmental awareness reflected in the last legislative documents $[1,2]$ has lead to an increasing number of industrial plants designed for the treatment of different organic wastes with the aim to avoid or reduce landfilling of non-stable organic materials. The bulk municipal solid waste stream (MSW, which can contain $40-60 \%$ of organic materials) and the source-

Abbreviations: $\mathrm{AT}_{4}$, cumulative oxygen consumption during 4 days $\left(\mathrm{g}_{2} / \mathrm{kg} \mathrm{DM}\right)$; $\mathrm{BOD}$, biochemical oxygen demand $\left(\mathrm{g} \mathrm{O}_{2} / \mathrm{L}\right) ; \mathrm{BP}_{\mathrm{L} 21}$, biogas production, liquid sample, 21 days $(\mathrm{L} / \mathrm{kg} \mathrm{DM})$; $\mathrm{BP}_{\mathrm{LF}}$, biogas production, liquid sample, final $(\mathrm{L} / \mathrm{kg} \mathrm{DM})$; $\mathrm{BP}_{\mathrm{S} 21}$, biogas production, solid sample, 21 days $(\mathrm{L} / \mathrm{kg} \mathrm{DM})$; $\mathrm{BP}_{\mathrm{SF}}$, biogas production, solid sample, final ( $\mathrm{L} / \mathrm{kg} \mathrm{DM})$; COD, chemical oxygen demand $\left(\mathrm{g} \mathrm{O}_{2} / \mathrm{L}\right)$; DM, dry matter (\%); DOC, dissolved organic carbon ( $\mathrm{gC} / \mathrm{L})$; $\mathrm{DRI}_{\mathrm{i}}$, dynamic respiration index, instantaneous $\left(\mathrm{g} \mathrm{O}_{2} \mathrm{~kg} \mathrm{DM}^{-1} \mathrm{~h}^{-1}\right)$; $\mathrm{DRI}_{24 \mathrm{~h}}$, dynamic respiration index, average of maximum values during $24 \mathrm{~h}\left(\mathrm{~g} \mathrm{O}_{2} \mathrm{~kg} \mathrm{DM}^{-1} \mathrm{~h}^{-1}\right)$; DRI $\max$, dynamic respiration index, absolute maximum ( $\mathrm{g} \mathrm{O}_{2} \mathrm{~kg} \mathrm{DM}^{-1} \mathrm{~h}^{-1}$ ); VS, volatile solids (\%, dry matter basis); SRI, static respiration index ( $\mathrm{g} \mathrm{O}_{2} \mathrm{~kg} \mathrm{DM}^{-1} \mathrm{~h}^{-1}$ ); TOC, total organic carbon (\%, dry matter basis).

* Corresponding author. Tel.: +3493 5811019; fax: +34 935812013.

E-mail address: antoni.sanchez@uab.cat (A. Sánchez). selected organic fraction of municipal solid waste (OFMSW, with an organic content over $80 \%$ ) have deserved special attention from the European authorities. As a result, MSW and OFMSW are being treated in a large number of different facilities such as mechanical-biological treatment (MBT), anaerobic digestion (often called "methanization") and composting plants. The main objective of these plants is to reduce the content of waste biodegradable organic matter in order to reduce its environmental impacts when landfilled (e.g. odour production, self-heating and selfcombustion, biogas production, leachate and pathogen re-growth). Lower impacts mean higher biological stability of the organic matter as this parameter correlates well with waste impacts [3].

A current definition of biological stability was proposed by Lasaridi and Stentiford [4], i.e. biological stability determines the extent to which readily biodegradable organic matter has decomposed. It identifies the actual point reached in the decomposition process and represents a gradation on a recognized scale of values, which thus enables comparison of the decomposition processes.

If the treatment efficiency of the waste biological treatment plants has to be determined a representative measure of the biological stability must then be used. This measure would permit the 
Table 1

Selection of parameters and conditions used in methods for the determination of organic matter stability (VS: volatile solids, DM: dry matter)

\begin{tabular}{|c|c|c|c|c|c|c|}
\hline Reference & Inoculation & Amount of sample & Water content & Temperature & Test duration & Results expression \\
\hline \multicolumn{7}{|l|}{ Aerobic } \\
\hline [12] & No & $10-13 \mathrm{~kg}$ & $75 \%$ water holding capacity & Self-heated & $<4$ days & $\mathrm{mg} \mathrm{O}_{2} \mathrm{~kg} \mathrm{VS}^{-1} \mathrm{~h}^{-1}$ \\
\hline [29] & Yes & $500 \mathrm{~g}$ & $50 \%$ & $58^{\circ} \mathrm{C}$ & 4 days expandable & $\mathrm{mg} \mathrm{O}_{2} / \mathrm{g} \mathrm{VS}$ \\
\hline [9] & No & $100 \mathrm{~g}$ & $40-60 \%$ & $25^{\circ} \mathrm{C}$ & 7 days & $\mathrm{mgCO}_{2} \mathrm{~g} \mathrm{DM}^{-1} \mathrm{~d}^{-1}$ \\
\hline [31] & No & $40 \mathrm{~g}$ & Saturation + empty filtration & $20^{\circ} \mathrm{C}$ & 4 days + lag phase & $\mathrm{mg} \mathrm{O}_{2} / \mathrm{g} \mathrm{DM}$ \\
\hline [33] & Yes & $400 \mathrm{~g}$ & $50 \%$ & $35^{\circ} \mathrm{C}$ & 4 days & $\mathrm{mg} \mathrm{O}_{2} / \mathrm{g} \mathrm{DM}$ or $\mathrm{mg} \mathrm{O}_{2} / \mathrm{g} \mathrm{VS}$ \\
\hline \multicolumn{7}{|l|}{ Anaerobic } \\
\hline [31] & Yes & $50 \mathrm{~g}$ & $50 \mathrm{~g} \mathrm{DM}+50 \mathrm{~mL}$ inoculum $+300 \mathrm{~mL}$ water & $35^{\circ} \mathrm{C}$ & 21 days + lag phase & $\mathrm{L} / \mathrm{kg} \mathrm{DM}$ \\
\hline [33] & Yes & $20 \mathrm{~g}$ & $20 \mathrm{~g}$ VS $+50 \mathrm{~mL}$ inoculum $+200 \mathrm{~mL}$ solution & $35^{\circ} \mathrm{C}$ & 100 days & $\mathrm{L} / \mathrm{kg}$ VS \\
\hline
\end{tabular}

evaluation of current working plants, the improvement of the biological treatment process, the design of optimized facilities and the potential impact of the final products.

Traditionally, total organic matter content (OM) measured as volatile solids (VS) has been used to monitor the evolution of composting processes [5]. However, when VS content is used in MSW streams, it results in an overestimation of its biodegradable organic matter content because of the presence of non-biodegradable volatile materials such as plastics which are not biodegradable under the normal operating conditions found in MBT, anaerobic digestion or composting plants. Moreover, VS content depends on each raw material characteristics. Other related measures such as total organic carbon (TOC) [6] or dissolved organic carbon (DOC) [7] have been used also for this purpose, but they suffer of the same problem indicated for VS.

In the wastewater field, a standard and accepted method for the determination of readily biodegradable organic matter already exists: the biochemical oxygen demand (BOD). However, in the solid waste management it does not exist a consensus within the scientific community about the methodology used to determine the biological stability in solid materials. To reach this goal, some research groups are working on this field [8-10] and some assays have been developed under aerobic [11-14] and anaerobic conditions $[15,16]$. The assays studied are usually based on respirometric techniques (static and dynamic) and methanogenic activity assays. Recently, acceptable correlations between anaerobic and aerobic indices determined of solid state samples have been published, although the number of samples studied is still rather limited $[17,18]$. Another possible approach is the use of suspended-solid samples and the measure of consumption of dissolved oxygen, as it is carried out in the SOUR test, which has been recently examined for precision in terms of repeatability and reproducibility [19].

The developed tests have been used for different purposes such as the monitoring of a biological treatment process of organic wastes [20-22] or the characterization of the biological stability of the final product obtained $[23,24]$. Since the determination of waste stability is a crucial aspect to fulfil the legal requirements necessary for final waste disposal, some works have been focused on this point, and some correlations between respiration activity and humification indices have been presented [25]. Also, oxygen uptake rate (OUR) has been used to estimate the production term in the resolution of energy and mass balances for process modelling [26-28].

At present, some standards have been already proposed $[9,29,30]$. Some of these methods have been also considered in the European legislation drafts [1] and adopted in national regulations by some European countries such as Germany [31], Italy [32] or England and Wales [33].

Table 1 shows the test conditions for some of the national standards defined for biological stability determination under aerobic and anaerobic conditions. As can be observed, the methodologies proposed differ in many key aspects such as the use of an inocu- lum, the amount of sample analysed, the water content, the assay temperature (mesophilic or thermophilic) or the test duration. Moreover, even the expression of the results (oxygen uptake rate or cumulative consumption) and the units (dry or volatile solids basis) are different among the test published.

Although some authors present partial comparisons between static and dynamic respirometric approaches or some correlations between indices used for biodegradable organic matter determination $[8,14,34,35]$, this is, to our knowledge, the first study where a massive comparison of chemical and biological indices and methods is carried out. The objectives of this research are therefore (i) to study the suitability of the methods proposed by different authors or institutions for the biological stability determination in samples from a MBT plant, obtained at different stages of their biodegradation, (ii) to compare the two main groups of methods proposed (aerobic and anaerobic), (iii) to determine the correlations among the methods studied, and (iv) to determine the efficiency of the treatment of biodegradable organic matter in the MBT studied, based on some selected indices.

\section{Materials and methods}

\subsection{Mechanical-biological treatment plant}

The MBT plant studied is located in the province of Umbria (Italy). Non-selected MSW were mechanically pre-treated by a sieve with a cut-off of $50 \mathrm{~mm}$. The fraction of material with a size smaller than $50 \mathrm{~mm}$ ( $40 \%$ of the total income) was biologically treated using an aerobic process. This process consisted of an aerated (air-flow supplied was of $10 \mathrm{~m}^{3} \mathrm{~h}^{-1} \mathrm{mg}^{-1}$ wet weight) and turned windrow (turning and watering occurred twice a week), which is typically used in composting systems. The normal operation of the plant is a biological process of 45 days to obtain a stabilized product prior to landfilling according to local regulations (dynamic respiration index below $1 \mathrm{~g} \mathrm{O}_{2} \mathrm{~kg} \mathrm{VS}^{-1} \mathrm{~h}^{-1}$ ). In the present work, the biological process was extended to 63 days for the purpose of this study. A schematic diagram of the MBT plant is shown in Fig. 1.

\subsection{Materials}

Samples were collected during October-November 2005 at different days of the biological treatment process: 0 (initial sample), 32,42 and 63 (final sample). Analysis were carried out on a representative sample $(20 \mathrm{~kg})$ obtained by mixing nine subsamples of about $2 \mathrm{~kg}$ each, taken from different points through the bulk material inside the reactor.

\subsection{Expression of biological indices}

As shown in Table 1, biological indices are both expressed in two bases: dry matter (DM) and volatile solids (VS). In this work, 


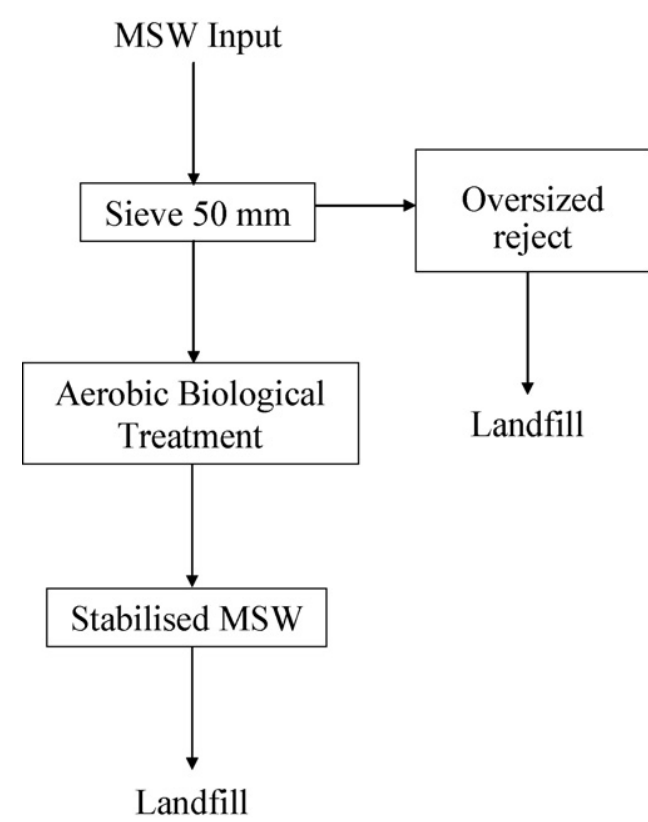

Fig. 1. Scheme of the mechanical-biological treatment studied.

the basis selected for the expression and comparison of the studied indices has been dry matter. This selection is based on the presence in MSW of significant amounts of non-biodegradable volatile matter (e.g. plastics), which is accounted in the volatile solids determination obtained by combustion of the sample.

\subsection{Aerobic methods}

\subsubsection{Dynamic methods}

The dynamic respiration index (in general, DRI) was measured using the method suggested by Adani et al. $[12,13,20]$, which is determined in a $20-\mathrm{L}$ adiabatic respirometric reactor (Costech International, Cernusco S.N., Italy; DiProVe, Milan, Italy). The respirometer consists of an insulated container (the respirometric reactor), a control cabinet, an air supply system, a personal computer and a biofilter. A Clark-type temperature compensation electrode and a differential-pressure electronic transmitter ensured both oxygen and airflow measurements every $10 \mathrm{~s}$. The instantaneous data were then sent to an in-house developed software for DRI calculation. An extensive description of the scientific apparatus was previously reported [12].

The oxygen uptake rate obtained under dynamic conditions was determined by measuring the difference in oxygen concentration $\left(\mathrm{mLL}^{-1}\right)$ between the inlet and outlet air flow that had passed through the biomass. The instantaneous dynamic respiration index $\left(\mathrm{DRI}_{\mathrm{i}}\right)$ was then calculated as

$\mathrm{DRI}_{\mathrm{i}}\left(\mathrm{g} \mathrm{O}_{2} \mathrm{~kg}^{-1} \mathrm{DM} \mathrm{h}^{-1}\right)=\frac{\mathrm{Q} \Delta \mathrm{O}_{2} 31.98}{1000 \mathrm{Vg} X_{\mathrm{DM}}}$

where $\mathrm{DRI}_{\mathrm{i}}$ is the instantaneous DRI, $Q(\mathrm{~L} / \mathrm{h})$ the airflow, $\Delta \mathrm{O}_{2}(\mathrm{~mL} / \mathrm{L})$ the difference in oxygen concentration in the inlet and outlet air flow of the reactor, 1000 is the conversion factor from $\mathrm{mL}$ to $\mathrm{L}, \mathrm{Vg}$ $(\mathrm{L} / \mathrm{mol})$ the volume occupied by one mole of gas at inlet air temperature, $31.98(\mathrm{~g} / \mathrm{mol})$ is the molecular weight of $\mathrm{O}_{2}$, and $X_{\mathrm{DM}}(\mathrm{kg})$ the weight of dry total solids of the sample.

Tests were performed setting an $\mathrm{O}_{2}$ concentration of $140 \mathrm{~mL} \mathrm{~L}^{-1}$ (14\%) in the outlet airflow to ensure aerobic conditions during the entire DRI measurement, by means of a feed-back control that automatically adapted the airflow rate. Test lasted $96 \mathrm{~h}$ and during this time oxygen concentration and DRI measurements were recorded hourly. Each trial was made in one single replicate, because of the large amount of sample used $(10-15 \mathrm{~kg})$, which is considered representative of the material [12].

The degree of biological stability measured by DRI was calculated using three methods representing different ways of expressing DRI from the value of $\mathrm{DRI}_{\mathrm{i}}$ :

(i) $\mathrm{DRI}_{24 \mathrm{~h}}$ : the average value of 24 instantaneous respiration indices $\left(\mathrm{DRI}_{\mathrm{i}}\right.$ ) obtained during the most intense $24 \mathrm{~h}$ of biological activity (highest values of $\mathrm{DRI}_{\mathrm{i}}$ ).

(ii) $\mathrm{DRI}_{\max }$ : the instantaneous maximum respiration rate registered during the entire test.

(iii) $\mathrm{AT}_{4}$ : the cumulative value of oxygen consumption recorded during $96 \mathrm{~h}$ ( 4 days). This value was obtained by numerical integration of $\mathrm{DRI}_{\mathrm{i}}$ values obtained during $96 \mathrm{~h}$ and is given as $\mathrm{g} \mathrm{O}_{2} / \mathrm{kg} \mathrm{DM}$.

\subsubsection{Static methods}

Static respiration index (SRI) was determined using a static respirometer based on the model previously described by Iannotti et al. [36] and according to the method described by Barrena et al. [14]. Briefly, the drop of oxygen content in a flask containing a waste representative sample $(250 \mathrm{~g})$ was monitored with an oxygen meter (Lutron 5510, Lutron, Taiwan) connected to a personal computer(RS232 communication protocol) with an in-house developed software to register oxygen values. Assay temperature was fixed at $37^{\circ} \mathrm{C}$. Previously to the respirometric test, samples were adjusted to a moisture content of $50-60 \%$ and incubated during $18 \mathrm{~h}$ at this temperature. During incubation samples were continuously aerated with previously humidified air at the sample temperature. Once incubation was finished, air supply was stopped and drop of the $\mathrm{O}_{2}$ level was recorded every $15 \mathrm{~s}$ for $90 \mathrm{~min}$. In all the SRI determinations three replicates were used, being the standard deviation in the range of $10 \%$ [14]. After oxygen measurement, the total volume of free air space in each sample flask was determined. The SRI of the sample was calculated from the slope in a linear segment on the chart $\mathrm{O}_{2}$ (\%) versus time using:

SRI $\left(\mathrm{g} \mathrm{O}_{2} \mathrm{~kg}^{-1} \mathrm{DM} \mathrm{h}^{-1}\right)=\frac{V \times P \times 31.98 \times S \times 60}{R \times T \times X_{\mathrm{DM}}}$

where $V(\mathrm{~L})$ is the volume of air in the flask, $P($ atm $)$ the atmospheric pressure at elevation of measurement (atm), $31.98(\mathrm{~g} / \mathrm{mol})$ the oxygen molecular weight, 60 the conversion factor from minutes to hours, $s\left(\mathrm{~mol} \mathrm{O}_{2} \mathrm{~mol}^{-1} \mathrm{~min}^{-1}\right)$ the slope of the oxygen drop during the respiration test in $\mathrm{O}_{2}$ percentage per minute divided by 100 , $R\left(0.08206 \mathrm{Latm} \mathrm{mol}^{-1} \mathrm{~K}^{-1}\right)$ the ideal gas constant, $T(\mathrm{~K})$ the temperature $(310 \mathrm{~K})$, and $X_{\mathrm{DM}}(\mathrm{kg})$ the weight of dry total solids of the sample.

\subsection{Anaerobic methods: biogas production}

\subsubsection{Solid state}

Two hundred grams of a wet representative waste sample were used in this test. Sample was mixed in a weight ratio 1:1 with an inoculum coming from the output of an industrial solid state anaerobic digester located in Barcelona (Spain). No water was added to this mixture.

The mixture was incubated in a water bath at $35^{\circ} \mathrm{C}$ in a sealed aluminium bottle with a working volume of $1 \mathrm{~L}$. Before each experiment, the bottles were purged with nitrogen gas to ensure anaerobic conditions. Each bottle was provided with a ball valve connected to a pressure digital manometer, which allowed the determination of the biogas pressure. The bulk density of the mixture was determined in order to calculate the headspace volume 
Table 2

Chemical parameters obtained in the samples from the MBT plant

\begin{tabular}{|c|c|c|c|c|c|c|}
\hline Sample & Moisture (\%) & $\begin{array}{l}\text { Volatile solids } \\
\text { (\%, DM basis) }\end{array}$ & $\mathrm{pH}$ & $\operatorname{COD}\left(\mathrm{g} \mathrm{O}_{2} / \mathrm{L}\right)$ & $\begin{array}{l}\text { Total organic carbon } \\
\text { (\%, DM basis) }\end{array}$ & $\begin{array}{l}\text { Dissolved organic } \\
\text { carbon }(\mathrm{g} \mathrm{C} / \mathrm{L})\end{array}$ \\
\hline Initial (0 days) & 48.1 & $50.4 \pm 0.8 \mathrm{a}$ & 6.78 & $5.72 \pm 0.11 \mathrm{a}$ & $26.1 \pm 0.03 a$ & $2.01 \pm 0.01 \mathrm{a}$ \\
\hline 32 days & 37.1 & $44.1 \pm 1.3 \mathrm{~b}$ & 7.05 & $6.47 \pm 0.02 b$ & $23.6 \pm 1.07 \mathrm{a}$ & $2.27 \pm 0.18 \mathrm{a}$ \\
\hline 42 days & 28.7 & $45.8 \pm 2.1 \mathrm{~b}$ & 7.32 & $4.02 \pm 0.01 \mathrm{c}$ & $20.1 \pm 0.40 \mathrm{a}$ & $1.65 \pm 0.01 \mathrm{a}$ \\
\hline Final (63 days) & 17.4 & $47.8 \pm 0.6 b$ & 8.34 & $3.56 \pm 0.08 d$ & $19.7 \pm 0.21 \mathrm{a}$ & $1.39 \pm 0.03 b$ \\
\hline Reduction (\%) & - & - & - & 37.8 & 24.5 & 30.8 \\
\hline
\end{tabular}

Consecutive parameters with different letters are statistically different.

of the bottles. During the test, the bottles were shaken once a day. Biogas production was calculated from the pressure in the bottle and the headspace volume. Excessive pressure in the bottle was released by purging the biogas produced (25-30 times during the experiment). Biogas composition was also routinely measured.

Tests were carried out in triplicate and the results obtained at 21 days $\left(\mathrm{BP}_{\mathrm{S} 21}\right)$ and at the end of the test when no significant biogas production was detected $\left(\mathrm{BP}_{\mathrm{SF}}\right)$ are expressed as biogas volume (L) produced at normal conditions ( $T=273 \mathrm{~K}, P=1$ bar) per kilogram of dry matter. A triplicate measure of the inoculum biogas production was carried out as a blank and deducted from the biogas production of the waste samples. None of the samples analysed presented acidification due to an excessive production of volatile fatty acids.

Biogas composition was analysed by gas chromatography (PerkinElmer AutoSystem XL Gas Chromatograph) with a thermal conductivity detector and using a column Hayesep $3 \mathrm{~m} \mathrm{1/8}$ in. 100/120. Volatile fatty acids (VFA) were determined by gas chromatography (PerkinElmer AutoSystem XL Gas Chromatograph) with a flame ionization detector (FID) and a column HP Innowax $30 \mathrm{~m} \times 0.25 \mathrm{~mm} \times 0.25 \mu \mathrm{m}$. The details of biogas and VFA analysis can be found elsewhere [37].

\subsubsection{Liquid state}

The test is similar to that of the solid state and the results are expressed in the same units. However, in this case dry samples were ground mechanically until a particle size of about $1 \mathrm{~mm}$ was achieved (standard size). These samples were then placed in $60 \mathrm{ml}$ glass vials with a stopper equipped with a metal ring and a pierceable silicon septum and incubated in a thermostat bath at $35^{\circ} \mathrm{C}$. One millilitre syringes were used for biogas sampling. Syringes pistons were lubricated with silicon fat to permit movement when even only slight pressure developed inside the vials. Upon closure nitrogen was insufflate continuously to guarantee perfect anaerobiosis. One gram of dry sample plus $1 \mathrm{~g}$ of an inoculum (anaerobic sludge, on dry basis) were placed in the vials and enough distilled water was added to achieve a dry matter content of $50 \mathrm{~g} \mathrm{~kg}^{-1}$ wet weight (liquid phase). Thereafter, the quantitative production of biogas (expressed in $\mathrm{mL}$ ) was measured and so was the relative composition by means of gas chromatography using a gas chromatograph (Carlo Erba MegaSeries 5300, Italy), with a Mega capillary column about $25 \mathrm{~m}$ long, with a diameter of $0.32 \mathrm{~mm}$ and a FID detector. The gas used as carrier was nitrogen at the pressure of $20 \mathrm{kPa}$, whereas the flame was fed with a 2:1 mixture of air and hydrogen $(\mathrm{v} / \mathrm{v})$, the temperatures for injector and FID were 150 and $350^{\circ} \mathrm{C}$, respectively, whereas the oven was maintained constant at $35^{\circ} \mathrm{C}$. Tests were also carried out in triplicate.

\subsection{Analytical methods}

Representative samples of the material from different locations of the pile processed were used to carry out all the analytical tests. Moisture (sometimes expressed as dry matter or total solids), volatile solids (VS), pH, total organic carbon (TOC) and dissolved organic carbon (DOC) were determined according to the standard procedures [38].

The biochemical oxygen demand $\left(\mathrm{BOD}_{5}\right)$ and the chemical oxygen demand (COD) were determined using waste elutes. Elutes were obtained by water-extraction of waste using distilled water (1:10 ratio solid liquid) for $24 \mathrm{~h}$ under shaking (UNE-EN 124574:2002). VS, TOC, DOC, COD and $\mathrm{BOD}_{5}$ analyses were performed in triplicate.

\subsection{Statistical analysis}

Statistical significance of values obtained during the biological process for the different parameters shown in Tables 2, 3 and 5 was checked by means of the Levene $F$-test (variance analysis) and $t$ Student test (mean analysis) both at $5 \%$ level of probability using the SPSS 15.0 package software (SPSS International, Chicago, IL). As explained before, dynamic respiration index was made in one replicate, because of the large amount of sample used (10-15 kg), which is considered representative of the material [12].

\section{Results}

\subsection{Physico-chemical parameters}

The first step in the characterization of samples from the MBT plant was to analyse some selected chemical parameters related to the biodegradation process. Results are summarised in Table 2. Moisture content presented a significant decrease during the aer-

Table 3

Aerobic respiration indices obtained on a dry matter basis

\begin{tabular}{|c|c|c|c|c|c|}
\hline Sample & $\mathrm{BOD}_{5}\left(\mathrm{~g} \mathrm{O}_{2} / \mathrm{L}\right)$ & $\begin{array}{l}\text { Static RI } \\
\left(\mathrm{g} \mathrm{O}_{2} \mathrm{~kg} \mathrm{DM}^{-1} \mathrm{~h}^{-1}\right)\end{array}$ & $\begin{array}{l}\text { Dynamic RI (maximum) } \\
\left(\mathrm{g} \mathrm{O}_{2} \mathrm{~kg} \mathrm{DM}^{-1} \mathrm{~h}^{-1}\right)\end{array}$ & $\begin{array}{l}\text { Dynamic RI (average } 24 \mathrm{~h}) \\
\left(\mathrm{g} \mathrm{O}_{2} \mathrm{~kg} \mathrm{DM}^{-1} \mathrm{~h}^{-1}\right)\end{array}$ & $\begin{array}{l}\text { Cumulative } \mathrm{AT}_{4} \text { (4 } \\
\text { days) }\left(\mathrm{g} \mathrm{O}_{2} / \mathrm{kg} \mathrm{DM}\right)\end{array}$ \\
\hline Initial (0 days) & $5.9 \pm 0.52 \mathrm{a}$ & $2.59 \pm 0.3 \mathrm{a}$ & 2.76 & 2.58 & 146 \\
\hline 32 days & $4.5 \pm 0.47 b$ & $1.18 \pm 0.03 b$ & 1.17 & 1.13 & 71.5 \\
\hline 42 days & $3.4 \pm 0.35 c$ & $0.95 \pm 0.08 c$ & 0.83 & 0.77 & 48.3 \\
\hline Final (63 days) & $2.5 \pm 0.25 \mathrm{~d}$ & $0.84 \pm 0.04 \mathrm{~d}$ & 0.64 & 0.60 & 31.7 \\
\hline Reduction (\%) & 58.6 & 67.6 & 76.8 & 76.7 & 78.3 \\
\hline
\end{tabular}

Consecutive parameters with different letters are statistically different. 
Table 4

Correlation matrix among all the parameters determined to study the biological stability of the samples

\begin{tabular}{|c|c|c|c|c|c|c|c|c|c|c|c|c|c|}
\hline & VS & COD & TOC & DOC & BOD & SRI & $\mathrm{DRI}_{\max }$ & $\mathrm{DRI}_{24 \mathrm{~h}}$ & $\mathrm{AT}_{4}$ & $\mathrm{BP}_{\mathrm{S} 21}$ & $\mathrm{BP}_{\mathrm{SF}}$ & $\mathrm{BP}_{\mathrm{L} 21}$ & $\mathrm{BP}_{\mathrm{LF}}$ \\
\hline VS & 1 & ns & ns & ns & ns & ns & ns & ns & ns & ns & ns & ns & ns \\
\hline COD & & 1 & $2.18^{* *}$ & ns & $1.06^{*}$ & ns & ns & ns & ns & ns & ns & ns & ns \\
\hline TOC & & & 1 & ns & $0.48^{*}$ & ns & ns & ns & $15.8^{*}$ & ns & ns & $25.3^{*}$ & $39.8^{*}$ \\
\hline DOC & & & & 1 & ns & ns & ns & ns & Ns & ns & $130^{*}$ & ns & ns \\
\hline BOD & & & & & 1 & ns & ns & ns & $32.3^{*}$ & ns & ns & $52.2^{*}$ & $80.2^{*}$ \\
\hline SRI & & & & & & 1 & $1.19^{* *}$ & $1.11^{*}$ & $61.4^{* *}$ & ns & ns & $93.8^{*}$ & $150^{*}$ \\
\hline $\mathrm{DRI}_{\max }$ & & & & & & & 1 & $0.93^{* * *}$ & $52.0^{* *}$ & ns & ns & $80.0^{*}$ & $127^{*}$ \\
\hline $\mathrm{DRI}_{24 \mathrm{~h}}$ & & & & & & & & 1 & $55.8^{* *}$ & ns & ns & $86.0^{*}$ & $137^{*}$ \\
\hline $\mathrm{AT}_{4}$ & & & & & & & & & 1 & ns & ns & $1.56^{* *}$ & $2.45^{* *}$ \\
\hline $\mathrm{BP}_{\mathrm{S} 21}$ & & & & & & & & & & 1 & $2.00^{* *}$ & ns & ns \\
\hline $\mathrm{BP}_{\mathrm{SF}}$ & & & & & & & & & & & 1 & ns & ns \\
\hline $\mathrm{BP}_{\mathrm{L} 21}$ & & & & & & & & & & & & 1 & $1.56^{* *}$ \\
\hline $\mathrm{BP}_{\mathrm{LF}}$ & & & & & & & & & & & & & 1 \\
\hline
\end{tabular}

When statistical significance was observed, the slope of the linear correlation is presented. $\left({ }^{* * *}\right),\left({ }^{* *}\right),\left({ }^{*}\right)$ Significant at $p<0.001,0.01$ and 0.05 , respectively; ns, not significant.

obic treatment of MSW, although water was added during the process. This is a typical behaviour that can be found in similar processes such as composting, since the increase of temperature to the thermophilic range implies water vaporization [39], in a phenomenon called "biodrying" [21]. In the case of the MBT plant studied, material temperature was in the range of $50-60^{\circ} \mathrm{C}$ during approximately 3 weeks, which permitted both waste biodrying and sanitation. Furthermore, $\mathrm{pH}$ showed a progressive tendency to alkalinisation, which is also typical in composting processes because of ammonia generation [39].

The rest of chemical parameters studied (VS, COD, TOC and DOC) presented in Table 2 are directly related to the content of organic carbon present in waste samples. However, none of these methods is capable of discerning between biodegradable and nonbiodegradable organic matter, since the principle of the methods is material combustion or strong chemical oxidation. This fact poses important problems when the efficiency of biological treatments needs to be evaluated in working plants or in the selection of a specific biological treatment during the design of a waste treatment plant. In the MBT studied, the reduction observed in the values of these parameters after the biological treatment is poor in all cases (Table 2), when compared to biological indices, as it will be discussed later. The reason in this case is probably the high content of non-biodegradable organic materials that are usually present in MSW streams (typically plastics). Moreover chemical parameters do not take into account qualitative aspects of organic matter such as biological indicators. The results obtained in the MBT plant are similar to those found in composting processes [40]. Other authors had previously found that COD did not show clear trends and did not allow any conclusions about compost stability [4]. In any case, it seems evident that these parameters should not be considered in the study of waste treatment plants based on biological process. This fact is also confirmed by the poor correlation found between biological and chemical methods (Table 4 ), which will be discussed later.

\subsection{Aerobic indices}

The aerobic indices estimated using different respirometric techniques are presented in Table 3 . Among them, $\mathrm{BOD}_{5}$ is universally used in the wastewater treatment field, whereas the rest of parameters (generically called respiration index) are commonly used in the composting field $[8,10]$. As it can be seen, the efficiency of the biological treatment, expressed as percentage of reduction, estimated using these indices is high in contrast with that estimated from reductions calculated from chemical data (Table 2). The lowest reduction resulted for the $\mathrm{BOD}_{5}$, which can be due to the use of a liquid extract of the waste, instead of using the waste itself, as it is done in respiration techniques. In fact, it was possible to estimate $\mathrm{AT}_{4}$ values from $\mathrm{BOD}_{5}$ values in Table 3 and considering the dry matter content of the samples. The results of this estimation showed a good approximation of $\mathrm{AT}_{4}$ values obtained from $\mathrm{BOD}_{5}$, except in the case of the initial sample, where the $\mathrm{AT}_{4}$ value estimated from $\mathrm{BOD}_{5}$ was very low. It is probable that this sample had a significant amount of non-extractable biodegradable organic matter, which is not accounted in the $\mathrm{BOD}_{5}$ test but degraded in the $\mathrm{AT}_{4}$ test, which uses the solid sample. In the rest of the samples, as the biological process progresses, the biodegradable organic matter is transformed into more soluble forms and, in consequence, extractable and measured in a $\mathrm{BOD}_{5}$ test. In consequence, $\mathrm{BOD}_{5}$ should not be used as a measure of the biological stability with fresh solid waste samples.

In relation to the use of respirometric techniques on solid state, the utilization of static or dynamic approaches has been previously discussed. The presence of a continuous air flow in dynamic systems favours the transport of oxygen to biomass and this fact results in DRI values higher than those of SRI [11]. Other authors have emphasized the importance of aeration rate on biodegradability fractionation on compost kinetics [41], as well as the importance of coupling the measures of respiration and porosity [42]. However, in the case of the samples studied, the differences between static and dynamic indices (DRI ${ }_{\max }$ or $\mathrm{DRI}_{24 \mathrm{~h}}$ ) were minimal (Table 3 ) and the correlations among them were highly significant (Table 4). It is possible that the relatively high porosity found in MSW permitted an optimal oxygen diffusion that makes biological activity the rate-limiting step even in static conditions. Nevertheless, it must be pointed that the system used for SRI determination has been previously optimized to minimize diffusion problems by using a low amount of sample [14]. In consequence, under these conditions, SRI can be a low-cost alternative to DRI methods for the study of MBT plants.

Other result that can be extracted from Table 4 is the excellent correlations found between rate-based respiration indices (SRI, $\mathrm{DRI}_{\max }$ and $\mathrm{DRI}_{24 \mathrm{~h}}$ ) and the cumulative oxygen consumption $\left(\mathrm{AT}_{4}\right)$. This fact is of special interest since cumulative consumption is used in some national regulations $[31,33]$ or standard procedures [29], probably due to the similarity with the $\mathrm{BOD}_{5}$ test. Therefore, the use of SRI or DRI as an alternative methodology to $\mathrm{AT}_{4}$ allows obtaining stability data as well as evaluating the efficiency of a MBT plant in a shorter time [13]. According to the aerobic biological indices, reduction of biodegradable organic matter in the MBT plant studied is in the range of $70-80 \%$, which is significantly higher than results obtained using only chemical parameters (Tables 2 and 3). The observed high efficiency in the reduction of biodegradable organic matter is in agreement with recently published works $[17,18]$, in which values around $70 \%$ are reported 
during the stabilization of mixed and source-selected municipal solid wastes. Therefore, it seems evident that respiration indices are the most suitable parameters to describe organic waste treatment plants based on biological operations. The use of chemical parameters such as COD is inadvisable, as reported in other works [35].

\subsection{Anaerobic indices}

Anaerobic indices based on biogas or methane production have been also used to monitor the biological treatment of solid wastes. However, their use is often limited to anaerobic digestion processes [16,37]. In this work, two biogas production (BP) tests using solid and liquid conditions were assayed. For each sample, BP was measured at 21 days because some national regulations use the cumulative biogas production during 21 days as a requirement to consider a waste as stabilised [31]. The ultimate biogas production was also determined.

The results obtained are presented in Table 5 . In relation to methane content, results showed that biogas determination occurred under stable methanogenesis (methane content over 50\%) and, consequently, no toxicity occurred. On the other hand, it can be observed that BP followed an expected pattern according to the biological stability; however, there are significant differences between solid and liquid tests. Thus, BP carried out in suspended liquid state reflects properly the biological stability, with a final reduction in $\mathrm{BP}_{\mathrm{L}}$ very similar to that obtained in aerobic respiration tests. The correlation between $\mathrm{BP}_{\mathrm{L}}$ (both at 21 days and ultimate) and $\mathrm{SRI}, \mathrm{DRI}_{24}$ and $\mathrm{DRI}_{\text {max }}$ is significant at $p<0.05$, whereas the significance between $\mathrm{BP}_{\mathrm{L}}$ and $\mathrm{AT}_{4}$ increases to $p<0.01$. These results demonstrate that anaerobic tests can be used to predict the stage of biodegradation of organic matter in solid waste samples. Also, as the biological process in the MBT plant studied is aerobic, these results can be interpreted in the sense that the organic matter biodegradation does not preferably affects aerobically biodegradable organic matter, because aerobic and anaerobic indices showed an identical evolution profile. These results have been recently confirmed in other MBT plants configurations [18], including anaerobic digestion processes, where a different evolution of these indices might have been expected if the anaerobic biodegradation had affected preferably to a specific pool of anaerobically biodegradable organic matter.

Results of BP carried out using solid samples and inoculum are also shown in Table 5. The values of reduction of $\mathrm{BP}_{S}$ are significantly lower than those of $\mathrm{BP}_{\mathrm{L}}$. A possible cause may be that anaerobic degradation in solid state was not complete. As no VFA were detected during the entire test, a possible explanation could be the difficulty in achieving a homogenous mixture, thus substrate is not easily available to microorganisms. This fact is more pronounced in the initial non-degraded sample, which presented a similar BP than that of 32-day sample (Table 5). In fact, there was no a statistically significant correlation between biogas production obtained at solid and liquid state (Table 4).

Nevertheless, from a practical point of view, an obvious drawback of the use of anaerobic methods is the long time necessary to complete the test. Even though duration of 21 days of the anaerobic test is accepted, this value is far from aerobic tests ( 4 days at most for $\mathrm{AT}_{4}$ ). Moreover, it must be pointed that other authors propose longer times to carry out methanogenic activity assays $[16,33]$. In the present case, the ratio of biogas produced at 21 days versus ultimate BP is in the range of $55-80 \%$. Although this type of correlations for anaerobic assays have not been found in literature, similar values are obtained when comparing $\mathrm{BOD}_{5}$ determined at 5 days and ultimate values in the field of aerobic wastewater treatment [43].

\section{Discussion}

\subsection{Comparison between aerobic and anaerobic indices}

As stated before, a complete correlation matrix among all the indices tested (chemical, aerobic and anaerobic) is presented in Table 4. Several useful conclusions can be extracted from this Table 4. Firstly, there was a poor correlation between chemical and biological parameters, both aerobic and anaerobic. Other works have found similar results when correlating chemical parameters such as COD with respiration indices [35]. It can be concluded that these chemical methods should not be, in general, used for the study of waste treatment plants including biological treatments.

On the other hand, the aerobic indices tested in this study, especially the group of respirometric indices, presented a high level of correlation among them, which clearly indicated that they can be used for the monitoring of the biodegradation of organic wastes in MBT or related plants. Also, respiration indices are strongly recommended when the overall efficiency of a waste treatment plant is to be evaluated [17,18,35].

Finally, it must be emphasized that anaerobic tests based on biogas production in liquid state also presented a high level of correlation with respiration tests. The ratio between cumulative ultimate biogas production $\left(\mathrm{BP}_{\mathrm{LF}}\right)$ and cumulative oxygen consumption $\left(\mathrm{AT}_{4}\right)$ is $2.45 \mathrm{~L}$ biogas produced per gram of oxygen consumed, being this ratio practically constant during the entire aerobic process. Other recent works have found significant correlations between aerobic respiration indices and biogas production tests under different conditions and with several typologies of waste samples $[17,18]$.

\subsection{Future implementation of biodegradability indices in MBT plants}

Today, there is an increasing growth of a solid waste treatment technology based on biological processes. However, the construction and operation of these new plants (MBT, anaerobic

Table 5

Results obtained for the biogas production on a dry matter basis for solid and liquid phase

\begin{tabular}{|c|c|c|c|c|}
\hline Sample & $\begin{array}{l}\text { Biogas production (solid, } \\
21 \text { days) (L/kg DM) }\end{array}$ & $\begin{array}{l}\text { Biogas production } \\
\left(\text { solid, final }^{1}\right)(\mathrm{L} / \mathrm{kg} \mathrm{DM})\end{array}$ & $\begin{array}{l}\text { Biogas production (liquid, } \\
21 \text { days) (L/kg DM) }\end{array}$ & $\begin{array}{l}\text { Biogas production } \\
\left.\text { (liquid, final }^{2}\right)(\mathrm{L} / \mathrm{kg} \mathrm{DM})\end{array}$ \\
\hline Initial (0 days) & $110 \pm 16$ a (62) & $172 \pm 37$ a (62) & $238 \pm 20$ a (66) & $352 \pm 25$ a (64) \\
\hline 32 days & $109 \pm 4$ a (64) & $185 \pm 9 \mathrm{a}(63)$ & $139 \pm 11 \mathrm{~b}(64)$ & $187 \pm 16 \mathrm{~b}(57)$ \\
\hline 42 days & $83 \pm 8 b(67)$ & $112 \pm 14 b(68)$ & $92 \pm 4 c(72)$ & $100 \pm 12 \mathrm{c}(57)$ \\
\hline Final (63 days) & $57 \pm 6$ b (67) & $76 \pm 10 \mathrm{~b}(68)$ & $55 \pm 1 \mathrm{~d}(74)$ & $78 \pm 8 d(74)$ \\
\hline Reduction (\%) & 48.2 & 55.8 & 76.9 & 77.8 \\
\hline
\end{tabular}

Biogas is expressed at $0{ }^{\circ} \mathrm{C}$ and 1 bar (normal conditions). Methane content $(\%, v / v)$ is presented between parentheses. Consecutive parameters with different letters are statistically different. (1) End of biogas production was reached at 100 days; (2) end of biogas production was reached at 75 days for initial and 32 -day sample and at 38 days for 42 days and final sample. 
or composting plants) has not been accompanied by the development of scientific knowledge and engineering principles applied to the evaluation of the efficiency of these facilities in the organic matter biodegradation. The use of indices based on biological properties of the samples studied (both aerobic and anaerobic) should be a starting point for the application of engineering and scientific criteria in the design of the future plants and the fulfilment of international requirements of stabilized solid wastes prior to landfilling.

\section{Conclusions}

From the results obtained it can be concluded that:

(1) Aerobic indices based on respiration techniques and determined under different conditions are useful indicators of the biological stability. Respiration indices based on the rate of oxygen uptake or the cumulative oxygen consumption can be successfully used for the prediction of the biological stability in heterogeneous solid wastes.

(2) Anaerobic methods based on biogas production correlated well with organic matter biodegradation, although significant differences were found in solid and liquid assays.

(3) A significant correlation was found between cumulative oxygen consumption and ultimate biogas production, which indicated that both indices can be used to express the degree of biological stability and to monitor a MBT plant.

(4) The results obtained in this research can be a basis for the quantitative measurement of the efficiency in the biodegradation of the readily organic matter, i.e. biological stability, in waste treatment plants, including MBT plants, anaerobic digestion of MSW and composting plants. However, a general consensus (scientific and politic) is necessary to decide what indices are to be used to characterize these facilities.

\section{Acknowledgement}

Financial support was provided by the Spanish Ministerio de Educación y Ciencia (Project CTM2006-00315).

\section{References}

[1] European Commission, Working document. Biological treatment of biowaste, 2nd draft, 2001, URL: http://www.compost.it/www/pubblicazioni_ on_line/biod.pdf (March 2008).

[2] European Commission, Working document on sludge, 3rd draft, 2003, URL: http://ec.europa.eu/environment/waste/sludge/pdf/sludge_en.pdf (March 2008).

[3] W. Muller, K. Fricke, H. Vogtmann, Biodegradation of organic matter during mechanical biological treatment of MSW, Compost Sci. Util. 6 (1998) 42-52.

[4] K.E. Lasaridi, E.I. Stentiford, A simple respirometric technique for assessing compost stability, Water Res. 32 (1998) 3717-3723.

[5] D.P. Komilis, R.K. Ham, The effect of lignin and sugars to the aerobic decomposition of solid wastes, Waste Manage. 23 (2003) 419-423.

[6] M. Ros, C. García, T. Hernández, A full-scale study of treatment of pig slurry by composting: Kinetic changes in chemical and microbial properties, Waste Manage. 26 (2006) 1108-1118.

[7] V. Fontanive, D. Effron, F. Tortarolo, N. Arrigo, Evaluation of parameters during composting of two contrasting raw materials, Compost Sci. Util. 12 (2004) 268-272.

[8] F. Adani, G. Gigliotti, F. Valentini, R. Laraia, Respiration index determination: a comparative study of different methods, Compost Sci. Util. 11 (2003) 144-151.

[9] B.J. Cooper, Stability (Biodegradability) Horizontal-7 WP4. Energy Research Center of the Netherlands, 2005. URL: http://www.ecn.nl/docs/society/ horizontal/hor_desk_7_stability.pdf (March 2008).

[10] R. Barrena, F. Vázquez, A. Sánchez, The use of respiration indices in the composting process: a review, Waste Manage. Res. 24 (2006) 37-47.

[11] B. Scaglia, F. Tambone, P.L. Genevini, F. Adani, Respiration index determination: dynamic and static approaches, Compost Sci. Util. 8 (2000) 90-98.
[12] F. Adani, P. Lozzi, P.L. Genevini, Determination of biological stability by oxygen uptake on municipal solid waste and derived products, Compost Sci. Util. 9 (2000) 163-178

[13] F. Adani, R. Confalonieri, F. Tambone, Dynamic respiration index as a descriptor of the biological stability of organic wastes, J. Environ. Qual. 33 (2004) 1866-1876.

[14] R. Barrena, F. Vázquez, M.A. Gordillo, T. Gea, A. Sánchez, Respirometric assays at fixed and process temperatures to monitor composting process, Bioresour. Technol. 96 (2005) 1153-1159.

[15] J. Ligthart, H. Nieman, Proceedings of the workshop on harmonisation of anaerobic biodegradation, activity and inhibition assays. EUR 20535 EN, European Commission Joint Research Centre, 2002.

[16] T.L. Hansen, J.E. Schmidt, I. Angelidaki, E. Marca, J.L.C. Jansen, H. Mosbæk, T.H. Christensen, Method for determination of methane potentials of solid organic waste, Waste Manage. 24 (2004) 393-400.

[17] R. Cossu, R. Raga, Test methods for assessing the biological stability of biodegradable waste, Waste Manage. 28 (2008) 381-388.

[18] S. Ponsá, T. Gea, L. Alerm, J. Cerezo, A. Sánchez, Comparison of aerobic and anaerobic stability indices through a MSW biological treatment process, Waste Manage. 28 (2008) 2735-2742.

[19] B. Scaglia, F.G. Erriquens, G. Gigliotti, M. Taccari, M. Ciani, P.L. Genevini, F. Adani, Precision determination for the specific oxygen uptake rate (SOUR) method used for biological stability evaluation of compost and biostabilized products, Bioresour. Technol. 98 (2007) 706-713.

[20] F. Adani, F. Tambone, A. Gotti, Biostabilization of municipal solid waste, Waste Manage. 24 (2004) 775-783.

[21] M. Sugni, E. Calcaterra, F. Adani, Biostabilization-biodrying of municipal solid waste by inverting air-flow, Bioresour. Technol. 96 (2005) 1331-1337.

[22] R. Barrena, E. Pagans, G. Faltys, A. Sánchez, Effect of inoculation dosing on the composting of source-selected organic fraction of municipal solid wastes, J. Chem. Technol. Biotechnol. 81 (2006) 420-425.

[23] F. Adani, C. Ubbiali, P.L. Genevini, The determination of biological stability of composts using the dynamic respiration index: the results of experience after two years, Waste Manage. 26 (2006) 41-48

[24] M. Gómez-Brandón, C. Lazcano, J. Domínguez, The evaluation of stability and maturity during the composting of cattle manure, Chemosphere 70 (2008) 436-444.

[25] C. Baffi, M.T. Dell'Abate, A. Nassisi, S. Silva, A. Benedetti, P.L. Genevini, F. Adani, Determination of biological stability in compost: a comparison of methodologies, Soil Biol. Biochem. 39 (2007) 1284-1293.

[26] T.L. Richard, H.V.M. Hamelers, A. Veeken, T. Silva, Moisture relationships in composting processes, Compost Sci. Util. 10 (2002) 286-302.

[27] R. Barrena, C. Cánovas, A. Sánchez, Prediction of temperature and thermal inertia effect in the maturation stage and stockpiling of a large composting mass, Waste Manage. 26 (2006) 953-959.

[28] D.P. Komilis, A kinetic analysis of solid waste composting at optimal conditions, Waste Manage. 26 (2006) 82-91.

[29] ASTM, Standard Test Method for Determining the Stability of Compost by Measuring of Oxygen Consumption, American Society for Testing and Materials, 1996, D5975-96.

[30] US Department of Agriculture and US Composting Council, Test methods for the examination of composting and compost, Edaphos International, Houston, TX, 2001.

[31] German Federal Ministry for the Environment, Nature Conservation and Nuclear Safety, Ordinance on environmentally compatible storage of waste from human settlements and on biological waste-treatment facilities of February 20, 2001. URL: http://www.bmu.de/english/publication/ current/publ/5263.php (Match 2008)

[32] E. Favoino, The EU legislation and the requirements following for national organic waste management strategies and policies, First Baltic Biowaste Conference, European Compost Network/Organic Recovery and Biological Treatment association, 2006. URL: http://www.recestonia.ee/ ecn/presentations/2\%20Enzo\%20Favoino.pdf (March 2008).

[33] A.R. Godley, A. Graham, K. Lewin, Estimating biodegradable municipal solid waste diversion from landfill: screening exercise to evaluate the performance of biodegradable test methods, R\&D Technical Report P1-513 (EP0173) phase 1, United Kingdom Environment Agency, 2005. URL: http://www.environmentagency.gov.uk/commondata/acrobat/rd_report_phase1_1113689.pdf (March 2008).

[34] M.T. Gea, R. Barrena, A. Artola, A. Sánchez, Monitoring the biological activity of the composting process: oxygen uptake rate (OUR), respirometric index (RI) and respiratory quotient (RQ), Biotechnol. Bioeng. 88 (2004) 520-527.

[35] B. Scaglia, F. Adani, An index for quantifying the aerobic reactivity of municipal solid wastes and derived waste products, Sci. Tot. Environ. 394 (2008) 183-191.

[36] D.A. Iannotti, T. Pang, B.L. Toth, D.L. Elwell, H.M. Keener, H.A.J. Hoitink, A quantitative respirometric method for monitoring compost stability, Compost Sci. Util. 1 (1993) 52-65.

[37] A. Fernández, A. Sánchez, X. Font, Anaerobic co-digestion of a simulated organic fraction of municipal solid wastes and fats of animal and vegetable origin, Biochem. Eng. J. 26 (2005) 22-28.

[38] APHA, Standard Methods for the Examination of Water and Wastewater, 20th ed., American Public Health Association, Washington, 1998.

[39] R.T. Haug, The Practical Handbook of Compost Engineering, Lewis Publishers, Boca Raton, FL, 1993. 
[40] T. Gea, A. Artola, X. Sort, A. Sánchez, Composting of residuals produced in the Catalan wine industry, Compost Sci. Util. 13 (2005) 168-174.

[41] A. de Guardia, C. Petiot, D. Rogeau, Influence of aeration rate and biodegradability fractionation on composting kinetics, Waste Manage. 28 (2008) 73-84.
42] L. Berthe, C. Druilhe, C. Massiani, A. Tremier, A. de Guardia, Coupling a respirometer and a pycnometer, to study the biodegradability of solid organic wastes during composting, Biosyst. Eng. 97 (2007) 75-88.

[43] Metcalf, Eddy, Wastewater Engineering: Treatment and Reuse, Fourth ed. McGraw-Hill, New York, 2003. 